\title{
Contribution of $\mathrm{V}_{\mathrm{H}}$ Replacement Products in Mouse Antibody Repertoire
}

\author{
Lin Huang ${ }^{19}$, Miles D. Lange ${ }^{19}$, Yangsheng $\mathrm{Yu}^{1}$, Song $\mathrm{Li}^{1}$, Kaihong Su ${ }^{1,2,3}$, Zhixin Zhang ${ }^{1,2 *}$ \\ 1 Department of Pathology and Microbiology, University of Nebraska Medical Center, Omaha, Nebraska, United States of America, 2 The Eppley Cancer Institute, \\ University of Nebraska Medical Center, Omaha, Nebraska, United States of America, 3 Department of Internal Medicine, University of Nebraska Medical Center, Omaha, \\ Nebraska, United States of America
}

\begin{abstract}
$\mathrm{V}_{\mathrm{H}}$ replacement occurs through RAG-mediated recombination between the cryptic recombination signal sequence (cRSS) near the $3^{\prime}$ end of a rearranged $V_{H}$ gene and the 23-bp RSS from an upstream unrearranged $V_{H}$ gene. Due to the location of the $c R S S, V_{H}$ replacement leaves a short stretch of nucleotides from the previously rearranged $V_{H}$ gene at the newly formed $\mathrm{V}$-D junction, which can be used as a marker to identify $V_{H}$ replacement products. To determine the contribution of $V_{H}$ replacement products to mouse antibody repertoire, we developed a Java-based $V_{H}$ Replacement Footprint Analyzer $\left(\mathrm{V}_{\mathrm{H}} \mathrm{RFA}\right)$ program and analyzed 17,179 mouse $\mathrm{lgH}$ gene sequences from the NCBI database to identify $\mathrm{V}_{\mathrm{H}}$ replacement products. The overall frequency of $\mathrm{V}_{\mathrm{H}}$ replacement products in these $\mathrm{IgH}$ genes is $5.29 \%$ based on the identification of pentameric $V_{H}$ replacement footprints at their $V$ - $D$ junctions. The identified $V_{H}$ replacement products are distributed similarly in IgH genes using most families of $V_{H}$ genes, although different families of $V_{H}$ genes are used differentially. The frequencies of $\mathrm{V}_{\mathrm{H}}$ replacement products are significantly elevated in $\mathrm{IgH}$ genes derived from several strains of autoimmune prone mice and in $\mathrm{IgH}$ genes encoding autoantibodies. Moreover, the identified $\mathrm{V}_{\mathrm{H}}$ replacement footprints in IgH genes from autoimmune prone mice or $\mathrm{IgH}$ genes encoding autoantibodies preferentially encode positively charged amino acids. These results revealed a significant contribution of $\mathrm{V}_{\mathrm{H}}$ replacement products to the diversification of antibody repertoire and potentially, to the generation of autoantibodies in mice.
\end{abstract}

Citation: Huang L, Lange MD, Yu Y, Li S, Su K, et al. (2013) Contribution of $\mathrm{V}_{\mathrm{H}}$ Replacement Products in Mouse Antibody Repertoire. PLoS ONE 8(2): e57877. doi:10.1371/journal.pone.0057877

Editor: Sebastian D. Fugmann, Chang Gung University, Taiwan

Received June 13, 2012; Accepted January 30, 2013; Published February 28, 2013

Copyright: (C) 2013 Huang et al. This is an open-access article distributed under the terms of the Creative Commons Attribution License, which permits unrestricted use, distribution, and reproduction in any medium, provided the original author and source are credited.

Funding: This study was supported by National Institutes of Health grants AI074948 (ZZ), Al076475 (ZZ), and AR059351 (KS), and by faculty developmental fund for ZZ and KS from University of Nebraska Medical Center, Eppley Cancer Institute, Omaha, Nebraska. The funders had no role in study design, data collection and analysis, decision to publish, or preparation of the manuscript.

Competing Interests: The authors have declared that no competing interests exist.

*E-mail: zhangj@unmc.edu

9 These authors contributed equally to this work.

\section{Introduction}

The variable region exons of the immunoglobulin (Ig) genes are generated through sequential rearrangement of previously separated $\mathrm{V}_{\mathrm{H}}, \mathrm{D}_{\mathrm{H}}$ (for heavy chain only), and $\mathrm{J}_{\mathrm{H}}$ gene segments catalyzed by the recombination activating gene products (RAG1 and RAG2) [1-5]. The specific joining of $\mathrm{V}_{\mathrm{H}}, \mathrm{D}_{\mathrm{H}}$, and $\mathrm{J}_{\mathrm{H}}$ gene segments is directed by the recombination signal sequences (RSSs) $[6,7]$. The RSS consists of a highly conserved heptamer and a nonamer, separated by a non-conserved spacer region with either 12-bp or 23-bp nucleotides [6-9]. Efficient recombination occurs between a 12 bp RSS- and a 23 bp RSS-flanked gene segments [6,7]. After RAG-mediated cleavage, the resulting double strand DNA breaks are repaired by the Non-Homologous End Joining (NHEJ) pathway $[4,5]$. The coding end hairpins are opened and re-joined to form the coding exon of Ig gene, whereas the signal ends are ligated to form an excision circle and released from the chromosomal DNA [6,7].

Rearrangement of Ig heavy $(\mathrm{IgH})$ chain genes starts with a $\mathrm{D}_{\mathrm{H}}$ to $\mathrm{J}_{\mathrm{H}}$ recombination on one allele of the $\mathrm{IgH}$ loci in early progenitor (pro) $\mathrm{B}$ cells followed by recombining a $\mathrm{V}_{\mathrm{H}}$ gene segment to the $\mathrm{DJ}_{\mathrm{H}}$ joint in late pro $\mathrm{B}$ cells [4,5]. If the rearrangement is non functional, pro $\mathrm{B}$ cells will start to rearrange the second $\mathrm{IgH}$ allele $[4,5]$. Functionally rearranged $\mathrm{IgH}$ genes will be expressed as the $\mu$ heavy chains to form pre-B cell receptors with the non-rearranged components, Vpre-B and lambda 5 [1015]. Signaling from the pre-BCR will stimulate pre B cell proliferation and subsequent IgL gene rearrangement $[14,15]$. The $\mathrm{IgL}$ gene variable region exon is generated by a one step rearrangement between a $\mathrm{V}_{\mathrm{L}}$ segment and a $\mathrm{J}_{\mathrm{L}}$ segment in the small precursor (pre-) B cells $[4,5,16]$. Due to the random recombination process, two thirds of the $\mathrm{V}(\mathrm{D}) \mathrm{J}$ rearrangement products might be out of reading frame and cannot express functional Ig peptides. Even if the $\mathrm{IgH}$ gene rearrangements are productive, they might fail to pair with the surrogate or conventional light chains. B cells lacking functional pre-B cell receptors (pre-BCRs) or B cell receptors (BCRs) cannot develop further along the B lineage pathway [14,17]. Moreover, functionally expressed BCRs may be self-reactive. In all these cases, early B lineage cells retain the abilities to initiate secondary RAGmediated recombination to alter the rearranged Ig genes, a process known as receptor editing [18-20].

Editing of rearranged $\mathrm{IgL}$ genes can occur through RAGmediated secondary recombination between any upstream $V_{L}$ gene to a downstream $\mathrm{J}_{\mathrm{L}}$ gene [21-26]. The intervening DNA fragment containing the previously rearranged $\mathrm{V}_{\mathrm{I}} \mathrm{J}_{\mathrm{L}}$ joint is 
deleted during the editing process [24-26]. As a default mechanism, pre-B cells with non-functional rearrangements on both $I g \kappa$ alleles can initiate de novo rearrangements at the $\operatorname{Ig} \lambda$ locus [26]. Accumulating studies indicated that non-functional or autoreactive $\mathrm{IgH}$ gene rearrangements can be edited through a $\mathrm{V}_{\mathrm{H}}$ replacement process [27-33]. $\mathrm{V}_{\mathrm{H}}$ replacement occurs through RAG-mediated recombination between a cryptic RSS embedded at the $3^{\prime}$ end of the rearranged $V_{H}$ gene with the 23 bp RSS from a upstream $V_{H}$ gene [31]. $V_{H}$ replacement was originally observed in murine pre-B cell leukemia cells, which generated functional $\mathrm{IgH}$ genes from non-functional $\mathrm{IgH}$ rearrangements $[27,28]$. The potential biological function of $\mathrm{V}_{\mathrm{H}}$ replacement in editing $\mathrm{IgH}$ genes encoding anti-DNA antibodies was demonstrated in a series of studies using engineered mouse models carrying knocked-in IgH $\mathrm{V}(\mathrm{D}) \mathrm{J}$ rearrangements encoding anti-DNA antibodies [29,34,35]; Later studies also provided evidence that $\mathrm{V}_{\mathrm{H}}$ replacement was employed to diversity the antibody repertoire in mouse carrying knocked-in IgH genes encoding anti-NP antibodies [30,36] and to rescue $\mathrm{B}$ cells with two alleles of non-functional $\mathrm{IgH}$ rearrangements [32,33]. Despite of these findings in engineered mice, evidence for ongoing $\mathrm{V}_{\mathrm{H}}$ replacement during $\mathrm{B}$ cell development in normal mouse and contribution of $\mathrm{V}_{\mathrm{H}}$ replacement products to the mouse antibody repertoire were lacking for a long time $[37,38]$.

Due to the location of the cRSS at the $3^{\prime}$ end of $\mathrm{V}_{\mathrm{H}}$ germline gene, $\mathrm{V}_{\mathrm{H}}$ replacement renews almost the entire $\mathrm{V}_{\mathrm{H}}$ coding region but leaves a short stretch of nucleotides from the previously rearranged $\mathrm{V}_{\mathrm{H}}$ gene at the newly formed $\mathrm{V}-\mathrm{D}$ junction [28,31]. These remnants can be used as $\mathrm{V}_{\mathrm{H}}$ replacement footprints to trace the occurrence of $\mathrm{V}_{\mathrm{H}}$ replacement and to identify potential $\mathrm{V}_{\mathrm{H}}$ replacement products through analyzing $\mathrm{IgH}$ gene sequences [31]. Our previous analysis of 412 human $\mathrm{IgH}$ gene sequences estimated that $\mathrm{V}_{\mathrm{H}}$ replacement products contribute to about $5 \%$ of the primary B cell repertoire in human [31]. A recent analysis of IgH genes generated from knock-in mice expressing $\mathrm{IgH}$ genes encoding anti-DNA antibodies showed that $7.5 \%$ of the newly generated $\mathrm{IgH}$ genes contain pentameric $\mathrm{V}_{\mathrm{H}}$ replacement footprints [39]. Similar frequency of $\mathrm{V}_{\mathrm{H}}$ replacement products were also found in $\mathrm{IgH}$ genes obtained from the wild type $\mathrm{B} 6$ mice [39].

To explore the contribution of $\mathrm{V}_{\mathrm{H}}$ replacement products to the diversification of mouse $\mathrm{IgH}$ repertoire, we developed a Java based $\mathrm{V}_{\mathrm{H}}$ replacement footprint analyzer $\left(\mathrm{V}_{\mathrm{H}} \mathrm{RFA}\right)$ program and analyzed 17,179 mouse IgH gene sequences from the National Center for Biotechnology Information (NCBI) database to identify $\mathrm{V}_{\mathrm{H}}$ replacement products. These results revealed a significant contribution of $\mathrm{V}_{\mathrm{H}}$ replacement products to the murine $\mathrm{IgH}$ repertoire and the enrichment of $\mathrm{V}_{\mathrm{H}}$ replacement products in several strains of autoimmune prone mice.

\section{Results}

\section{The Mouse IgH Sequence Repertoire}

To analyze a large number of $\mathrm{IgH}$ gene sequences and to identify potential $\mathrm{V}_{\mathrm{H}}$ replacement products, we developed a Java based $\mathrm{V}_{\mathrm{H}}$ Replacement Footprint Analyzer $\left(\mathrm{V}_{\mathrm{H}} \mathrm{RFA}\right)$ program. Using the $\mathrm{V}_{\mathrm{H}} \mathrm{RFA}$ program, we analyzed 17,179 mouse IgH gene sequences from the NCBI databases to identify $\mathrm{V}_{\mathrm{H}}$ replacement products. First, the potential $\mathrm{V}_{\mathrm{H}}, \mathrm{D}_{\mathrm{H}}$, and $\mathrm{J}_{\mathrm{H}}$ germline gene usage were assigned using the IMGT/V-QUEST program by sending batches of sequences using the $\mathrm{V}_{\mathrm{H}} \mathrm{RFA}$ program (shown in Table $\mathrm{S} 1)$. Based on the IgH CDR3 region sequences, clonally identical sequences were stripped out. There are 11309 unique $\operatorname{IgH}$ gene sequences; 10159 of them have clearly identifiable $\mathrm{V}_{\mathrm{H}}, \mathrm{D}_{\mathrm{H}}$, and $\mathrm{J}_{\mathrm{H}}$ genes; 9774 of them are productive and 373 of them are nonproductive $\mathrm{IgH}$ rearrangements. In these $\mathrm{IgH}$ genes, different families of $\mathrm{V}_{\mathrm{H}}$ genes are used differentially (Fig. 1). There are $63683(65 \%)$ functional $\mathrm{IgH}$ genes using the IGHV1/ $\mathrm{V}_{\mathrm{H}} \mathrm{J} 558$ family of $\mathrm{V}_{\mathrm{H}}$ genes; 911 (or $9.3 \%$ ) functional $\mathrm{IgH}$ genes using the IGHV5/ $\mathrm{V}_{\mathrm{H}} 7183$ family of $\mathrm{V}_{\mathrm{H}}$ genes. The other families of $\mathrm{V}_{\mathrm{H}}$ genes, including IGHV4/X-24, IGHV11/CP3, IGHV12/CH27, IGHV13/3609N, and IGHV15/VH15A, are used at much lower frequencies (Fig. 1A). Among the non-functional $\mathrm{IgH}$ rearrangements, the usages of most $\mathrm{V}_{\mathrm{H}}$ gene families are similar to those in functional $\mathrm{IgH}$ genes, but the usages of the IGHV5/ $\mathrm{V}_{\mathrm{H}} 7183$ and IGHV3/36-60 gene families are increased (Fig. 1A). Among different $\mathrm{D}_{\mathrm{H}}$ genes, the IGHD1-1 gene is used the most frequent in almost $39 \%$ of the $\mathrm{IgH}$ sequences (Fig. 1B). For the $\mathrm{J}_{\mathrm{H}}$ genes, the IGHJ2 gene is used the most frequent in $43 \%$ of $\mathrm{IgH}$ genes (Fig. 1C). It should be noted that these 17179 mouse $\mathrm{IgH}$ sequences were derived from about 861 published reports (Table S2), presumably from more than 861 experiments with different mice. This analysis represents a comprehensive view of the $\mathrm{IgH}$ repertoire of the current available mouse $\mathrm{IgH}$ gene sequences in the NCBI database.

\section{Identification of $\mathrm{V}_{\mathrm{H}}$ Replacement Products}

In the initial test, we use the $\mathrm{V}_{\mathrm{H}} \mathrm{RFA}$ program to identify potential $\mathrm{V}_{\mathrm{H}}$ replacement products in 271 mouse $\mathrm{IgH}$ gene sequences described previously [40]. Among them, 252 unique IgH genes have clearly identifiable $\mathrm{V}_{\mathrm{H}}, \mathrm{D}_{\mathrm{H}}$, and $\mathrm{J}_{\mathrm{H}}$ germline genes. Then, we searched for $\mathrm{V}_{\mathrm{H}}$ replacement footprint motifs with $3,4,5,6$, or 7 nucleotides within the $\mathrm{V}_{\mathrm{H}^{-}} \mathrm{D}_{\mathrm{H}}$ junction $(\mathrm{N} 1)$ regions of these $\mathrm{IgH}$ genes. $\mathrm{V}_{\mathrm{H}}$ replacement can only introduce $\mathrm{V}_{\mathrm{H}}$ replacement footprint in the $\mathrm{Nl}$ region. As an internal control, we searched for similar $\mathrm{V}_{\mathrm{H}}$ replacement footprint motifs in the $\mathrm{D}_{\mathrm{H}^{-}} \mathrm{J}_{\mathrm{H}}$ junction $(\mathrm{N} 2)$ regions of these $\mathrm{IgH}$ genes, which are likely generated by random nucleotide addition. The frequencies of 3, 4, and 5-mer $\mathrm{V}_{\mathrm{H}}$ replacement footprint motifs in the $\mathrm{N} 1$ regions are significantly higher than those in the $\mathrm{N} 2$ regions (Table 1, top), suggesting that the distribution of such motifs in the $\mathrm{Nl}$ region is not due to random nucleotide addition. Based on the identification of the pentameric $\mathrm{V}_{\mathrm{H}}$ replacement footprints within the $\mathrm{Nl}$ regions, we estimate that the frequency of $\mathrm{V}_{\mathrm{H}}$ replacement products is $5.5 \%$ in these 252 mouse $\mathrm{IgH}$ gene sequences (Table 1 , Top). If we consider the 4- or 3-mer of $\mathrm{V}_{\mathrm{H}}$ replacement footprints in the $\mathrm{N} 1$ regions, the frequencies of $\mathrm{V}_{\mathrm{H}}$ replacement products in these $252 \mathrm{IgH}$ genes will be $21.2 \%$ or $38 \%$, respectively (Table 1 , top and the identified $\mathrm{V}_{\mathrm{H}}$ replacement products with 4-mer $\mathrm{V}_{\mathrm{H}}$ replacement footprints are shown in Table S5).

Further analysis of the 14 identified $\mathrm{V}_{\mathrm{H}}$ replacement products validated the assignment of $\mathrm{V}_{\mathrm{H}}$ replacement footprints by the $\mathrm{V}_{\mathrm{H}}$ RFA program (Table 2). Theoretically, $\mathrm{V}_{\mathrm{H}}$ replacement occurs through an upstream $V_{H}$ gene replacing a downstream rearranged $\mathrm{V}_{\mathrm{H}}$ gene. Among these 14 identified potential $\mathrm{V}_{\mathrm{H}}$ replacement products, 11 of them were likely generated through upstream $\mathrm{V}_{\mathrm{H}}$ genes replacing downstream $\mathrm{V}_{\mathrm{H}}$ genes; 3 of them did not follow such order (Table 2).

\section{Contribution of $\mathrm{V}_{\mathrm{H}}$ Replacement Products to the Mouse IgH Repertoire}

Next, we analyzed the 11,309 unique mouse $\operatorname{IgH}$ gene sequences from the NCBI database using the $V_{H}$ RFA program to search for $\mathrm{V}_{\mathrm{H}}$ replacement products. We performed separated analyses to identify $\mathrm{V}_{\mathrm{H}}$ replacement footprints with $3,4,5,6$, and 7 nucleotides in the $\mathrm{V}_{\mathrm{H}}-\mathrm{D}_{\mathrm{H}}$ junction $(\mathrm{N} 1)$ regions. As internal controls, we also searched for the similar motifs in the $\mathrm{D}_{\mathrm{H}}-\mathrm{J}_{\mathrm{H}}$ junction (N2) regions. The frequencies of identified $\mathrm{V}_{\mathrm{H}}$ re- 


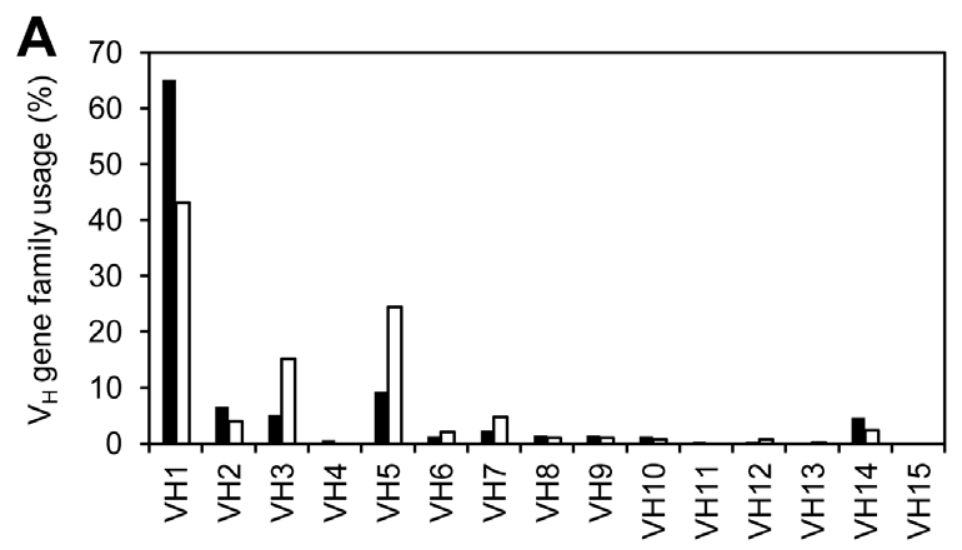

Functional $(n=9774)$

$\square$ Nonfunctional $(n=373)$
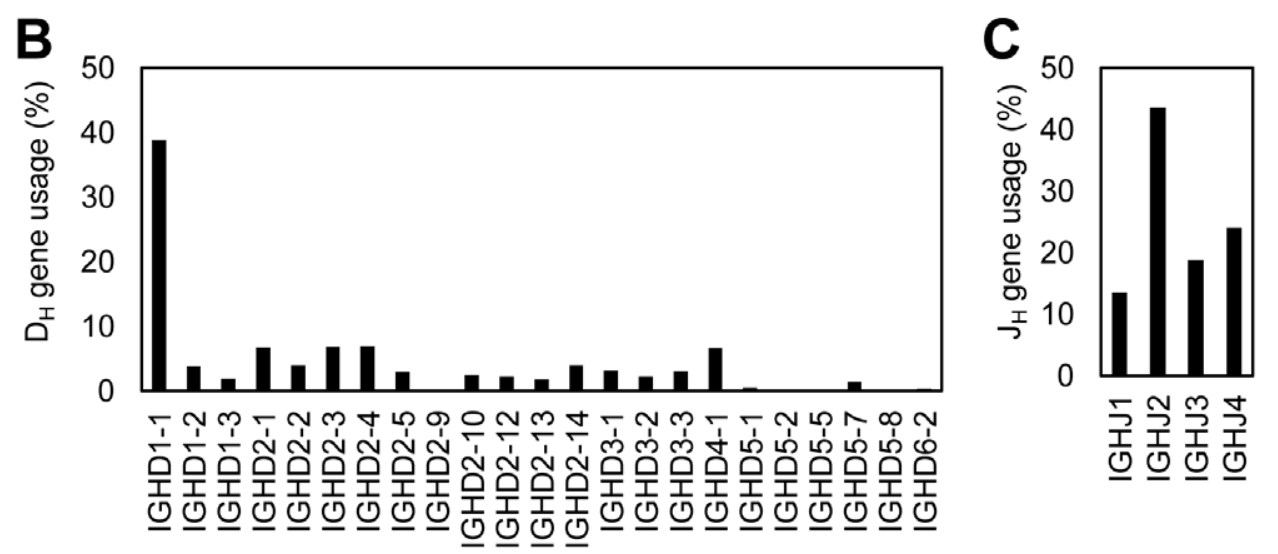

Figure 1. Immunoglobulin $\mathbf{V H}, \mathrm{DH}$, and $\mathrm{JH}$ gene usages in the mouse IgH sequence repertoire. The mouse IgH gene sequence data set containing 17,179 entries was downloaded from NCBI databases. The potential $\mathrm{V}_{\mathrm{H}}, \mathrm{D}_{\mathrm{H}}$, and $\mathrm{J}_{\mathrm{H}}$ germline gene assignments were performed using the IMGT/V-QUEST program by sending batches of sequences by the $V_{H}$ RFA program. Clonally redundant IgH sequences were removed if they contain identical CDR3 regions. The usages of different families of $V_{H}$ germline genes $(A)$, $D_{H}$ genes $(B)$, and $J_{H}(C)$ genes in the functional or non-functional unique $\mathrm{lg} \mathrm{H}$ genes were analyzed.

doi:10.1371/journal.pone.0057877.g001

placement footprints with $3,4,5,6$, or 7 nucleotides in the $\mathrm{N} 1$ regions are significantly higher than those in the $\mathrm{N} 2$ regions (Table 1, bottom). These results indicate that the presence of these motifs at the $\mathrm{N} 1$ region is not due to random nucleotide addition. With a stringent setting to search for the pentameric $\mathrm{V}_{\mathrm{H}}$ replacement footprints at the $\mathrm{N} 1$ regions, $5.29 \%$ of the $\mathrm{IgH}$ genes contain such motifs and can be assigned as potential $\mathrm{V}_{\mathrm{H}}$ replacement products. If we consider $\mathrm{V}_{\mathrm{H}}$ replacement footprints with 4 or 3 nucleotides, $15.95 \%$ or $33.55 \%$ of the $\operatorname{IgH}$ genes, respectively, contain such motifs and can be assigned as potential $\mathrm{V}_{\mathrm{H}}$ replacement products (Table 1, bottom). These results revealed a significant contribution of $\mathrm{V}_{\mathrm{H}}$ replacement products to the diversification of the murine $\mathrm{IgH}$ repertoire.

\section{Distribution of $V_{H}$ Replacement Products in IgH Genes Using Different Families of $\mathrm{V}_{\mathrm{H}}$ Genes}

As we showed earlier, different $\mathrm{V}_{\mathrm{H}}$ gene families are used at different frequencies in the 10159 mouse $\mathrm{IgH}$ gene sequences. Next, we analyzed the distribution of the identified $\mathrm{V}_{\mathrm{H}}$ replacement products with 5-mer footprint motifs in IgH genes using different $\mathrm{V}_{\mathrm{H}}$ gene families. Among all the IgH genes using different families of $\mathrm{V}_{\mathrm{H}}$ genes, the frequency of $\mathrm{V}_{\mathrm{H}}$ replacement products in $\mathrm{IgH}$ genes using the $\mathrm{VH} 2 / \mathrm{Q} 52$ genes is significantly higher than that in the overall mouse IgH sequences (Table 3). The frequencies of $\mathrm{V}_{\mathrm{H}}$ replacement products in $\mathrm{IgH}$ genes using the other $\mathrm{V}_{\mathrm{H}}$ gene families are quite similar. For example, although the IGHV1/ $\mathrm{V}_{\mathrm{H}} \mathrm{J} 558$ and IGHV5/ $/ \mathrm{V}_{\mathrm{H}} 7183$ families are used most frequently and the IGHV4/X-24, IGHV12/CH27, and IGHV14/SM7 families are used at very low frequencies, the frequencies of $\mathrm{V}_{\mathrm{H}}$ replacement products in $\mathrm{IgH}$ genes using the IGHV1/V ${ }_{\mathrm{H}} 558$, IGHV5/V $\mathrm{V}_{\mathrm{H}} 7183$, IGHV4/X-24, IGHV12/ CH27, and IGHV14/SM7 families are similar (Table 3). These results indicate that although different families of $\mathrm{V}_{\mathrm{H}}$ genes are used differentially during the primary $\mathrm{V}(\mathrm{D}) \mathrm{J}$ recombination, they are similarly targeted for secondary recombination during $\mathrm{V}_{\mathrm{H}}$ replacement. As an internal negative control, we analyzed the N1 regions of $\mathrm{IgH}$ genes using the $\mathrm{D}_{\mathrm{H}}$ proximal $\mathrm{V}_{\mathrm{H}} 5-2 / 7183.2$ gene. Among the 56 functional $\mathrm{IgH}$ genes using the $\mathrm{V}_{\mathrm{H}} 5-2 / 7183.2$ gene, there is no pentameric $\mathrm{V}_{\mathrm{H}}$ replacement footprints in the $\mathrm{Nl}$ regions. Such result provides supporting evidence that the presence of pentameric footprints in the $\mathrm{Nl}$ regions of mouse $\mathrm{IgH}$ genes is contributed by $\mathrm{V}_{\mathrm{H}}$ replacement.

\section{Enrichment of $\mathrm{V}_{\mathrm{H}}$ Replacement Products in IgH Genes Derived from Different Strains of Autoimmune Prone Mice and IgH Genes Encoding Autoantibodies}

To explore the biological significance of $\mathrm{V}_{\mathrm{H}}$ replacement in mouse, we analyzed the distribution of $\mathrm{V}_{\mathrm{H}}$ replacement products in $\mathrm{IgH}$ genes correlating with different keywords in the NCBI database. Based on the identification of 5-mer $\mathrm{V}_{\mathrm{H}}$ replacement footprints within the $\mathrm{N} 1$ regions, the frequencies of $\mathrm{V}_{\mathrm{H}}$ replacement products in $\mathrm{IgH}$ genes derived from $C 57 \mathrm{BL} / 6$ and 


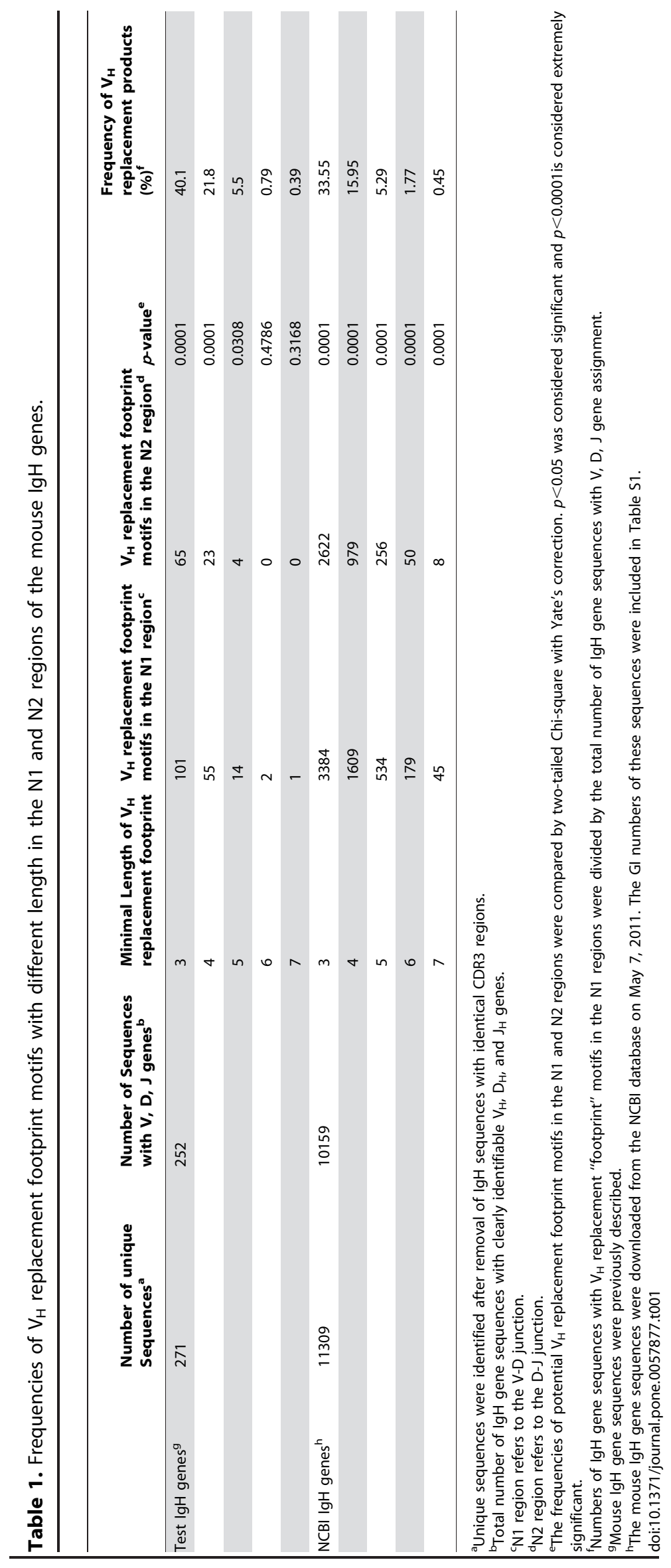


Table 2. List of potential $\mathrm{V}_{\mathrm{H}}$ replacement products in the test IgH sequences.

\begin{tabular}{|c|c|c|c|c|c|c|c|}
\hline Sequence ID & $V_{H}$ gene & $\mathbf{3}^{\prime} \mathbf{V}_{\mathbf{H}}$ & $\mathbf{P}$ & N1 & $\mathbf{D}_{\mathbf{H}}$ & Potential footprint donor & Position $^{a}$ \\
\hline FJ816520 & IGHV1S132 & tgtgcaaga & & gggaggacct & IGHD2-14 & IHGV8-10, IGHV8-14, IGHV8S2 & $\mathrm{Y}$ \\
\hline FJ150867 & IGHV14-3 & tgtgcaaga & & gggagaggggggcgtgatc & IGHD1-1 & IGHV3-3, IGHV10-3, IGHV13-1 & $\mathrm{Y}$ \\
\hline FJ150854 & IGHV1S132 & tgtgcaaga & & gcgaacg & IGHD2-12 & IGHV7-1 & $\mathrm{Y}$ \\
\hline GU907018 & IGHV1-9 & tgtgccaga & & ggagga & IGHD1-1 & IGHV8-10, IGHV8-14, IGHV8S2 & $\mathrm{Y}$ \\
\hline FJ816537 & IGHV1-74 & tgtgcaa & & $\underline{\text { gagagg }}$ & IGHD2-12 & IGHV3-3, IGHV10-3, IGHV13-1 & $\mathrm{Y}$ \\
\hline FJ816495 & IGHV1-47 & tgtgcaagg & & $\underline{\text { gagag }}$ & IGHD1-1 & IGHV3-3, IGHV10-3, IGHV13-1 & $\mathrm{Y}$ \\
\hline GU907010 & IGHV1-5 & tgtacaaga & & gagac & IGHD2-1 & IGHV10-1, IGHV12-3 & $\mathrm{Y}$ \\
\hline GU907038 & IGHV1-4 & tgtgcaaga & tc & $\underline{\text { gaagg }}$ & IGHD2-3 & IGHV3-1 & $\mathrm{Y}$ \\
\hline FJ816546 & IGHV1-4 & tgtgcaag & & gaagagg & IGHD1-1 & IGHV8-12, IGHV1-11, IGHV12-3 & $\mathrm{Y}$ \\
\hline FJ816592 & IGHV14-1 & $\operatorname{tgtg} c$ & & cagag & IGHD2-14 & IGHV2-6-7 & $\mathrm{Y}$ \\
\hline FJ816442 & IGHV14-1 & tgtgcta & & $\underline{\text { aaacctc }}$ & IGHD1-1 & IGHV2-3, IGHV2-6-6 & $\mathrm{Y}$ \\
\hline FJ816522 & IGHV2-9-1 & tgtgccagaga & tc & ggggatatcg & IGHD2-14 & IGHV7-3 & $\mathrm{N}$ \\
\hline GU906999 & IGHV14-3 & tgtgctaga & & ggagga & IGHD1-1 & IGHV8-10, IGHV8-14, IGHV8S2 & $\mathrm{N}$ \\
\hline GU906995 & IGHV14-3 & tgtgctgga & & ggagga & IGHD1-1 & IGHV8-10, IGHV8-14, IGHV8S2 & $\mathrm{N}$ \\
\hline
\end{tabular}

The identified $\mathrm{V}_{\mathrm{H}}$ replacement footprints in the $\mathrm{N} 1$ regions are underlined.

${ }^{a}$ The relative positions of the potential donors and recipient $V_{H}$ genes in the identified $V_{H}$ replacement product were analyzed to determine if the $V_{H}$ replacement occurred through an upstream $V_{H}$ gene replacing a downstream $V_{H}$ gene $(Y)$ or a downstream $V_{H}$ gene replacing an upstream gene $(N)$. Only functional $V_{H}$ germline genes were used in this analysis.

doi:10.1371/journal.pone.0057877.t002

$B A L B / c$ strains of mice are $3.17 \%$ and $5 \%$, respectively (Fig. 2A and Table S6). Such numbers may serve as the basal levels of $\mathrm{V}_{\mathrm{H}}$ replacement products in these mice. Comparing $\mathrm{IgH}$ genes derived from several strains of mice, the frequencies of $\mathrm{V}_{\mathrm{H}}$ replacement products are highly elevated in IgH genes derived from different strains of autoimmune prone mice (Fig. 2A). In particular, the frequencies of $\mathrm{V}_{\mathrm{H}}$ replacement product are elevated in $\mathrm{IgH}$ genes derived from lupus prone $\mathcal{N} Z B / \mathcal{N} Z W \mathrm{~F} 1, \mathcal{N} Z M 2410$, $M R L / l p r$, and SLE1/SLE3 mice. In IgH genes derived from mice carrying the spontaneous Fas ${ }^{\mathrm{lpr}}$ mutation $(M R L / M p 7-L p r / L p r)$, the frequency of $\mathrm{V}_{\mathrm{H}}$ replacement products is $15.38 \%$. In IgH genes from the Sle1/Sle3 mice, the frequency of $\mathrm{V}_{\mathrm{H}}$ replacement

Table 3. Frequencies of $\mathrm{V}_{\mathrm{H}}$ replacement products in IgH genes using different families of mouse $\mathrm{V}_{\mathrm{H}}$ genes.

\begin{tabular}{|c|c|c|c|}
\hline$V_{H}$ family & $\begin{array}{l}\text { Number of IgH gene } \\
\text { sequences }\end{array}$ & Motifs in the N1 region & Frequency of $V_{H}$ replacement products $(\%)^{a}$ \\
\hline VH1/J558 & 6530 & 314 & 4.81 \\
\hline VH2/Q52 & 665 & 55 & $8.27^{c}$ \\
\hline VH3/36-60 & 565 & 30 & 5.31 \\
\hline VH4/X-24 & 57 & 3 & 5.26 \\
\hline VH5/7183 & 998 & 68 & 6.81 \\
\hline VH6/J606 & 131 & 6 & 4.58 \\
\hline VH7S107 & 253 & 8 & 3.16 \\
\hline VH8/3609 & 139 & 9 & 6.47 \\
\hline VH9/VGAM3-8 & 144 & 11 & 7.64 \\
\hline VH10/VH10 & 127 & 4 & 3.15 \\
\hline VH11/CP3 & 37 & 0 & 0 \\
\hline VH12/CH27 & 43 & 3 & 6.98 \\
\hline VH13/3609N & 7 & 1 & 14.29 \\
\hline VH14/SM7 & 459 & 26 & 5.66 \\
\hline VH15/VH15A & 4 & 0 & 0 \\
\hline VH5-2/7183.2 & 56 & 0 & 0 \\
\hline
\end{tabular}


products is $30 \%$. These frequencies are significantly higher than that in the $B A L B / c$ or $C 57 B L / 6$ mice $(p<0.05$, two tailed Chisquare test) (Fig. 2A). The elevated levels of $\mathrm{V}_{\mathrm{H}}$ replacement products in autoimmune prone mice suggest that $\mathrm{V}_{\mathrm{H}}$ replacement products contribute to the generation of autoantibodies. Indeed, further analyses of the $\mathrm{IgH}$ genes encoding different antibodies showed that the frequencies of $\mathrm{V}_{\mathrm{H}}$ replacement products are $12.1 \%$ in $\mathrm{IgH}$ genes encoding ANA antibody and 9.34\% in $\mathrm{IgH}$ genes encoding anti-DNA antibodies. These levels are significantly higher than those in the $B A L B / c$ or $C 57 B L / 6$ mice. As a negative control, the frequency of $\mathrm{V}_{\mathrm{H}}$ replacement products in $\mathrm{IgH}$ genes obtained from mice immunized with NP is $3.66 \%$, which is similar to that in the $C 57 B L / 6$ mice. Taken together, these results provide the first information that $\mathrm{V}_{\mathrm{H}}$ replacement products are highly enriched in $\mathrm{IgH}$ genes derived from different strains of autoimmune prone mice and in IgH genes encoding anti-DNA and ANA autoantibodies.

Using the $\mathrm{V}_{\mathrm{H}} \mathrm{RFA}$ program, we also analyzed the frequencies of $\mathrm{V}_{\mathrm{H}}$ replacement products based on the 4- or 3-mer of $\mathrm{V}_{\mathrm{H}}$ replacement footprints in $\mathrm{IgH}$ genes derived these diseased subcategories. Extending the assignment of $\mathrm{V}_{\mathrm{H}}$ replacement products with considering the 4- and 3-mer $\mathrm{V}_{\mathrm{H}}$ replacement footprints clearly increases the frequencies of $\mathrm{V}_{\mathrm{H}}$ replacement products in $\mathrm{IgH}$ genes from all subcategories. With considering the 4-mer $\mathrm{V}_{\mathrm{H}}$ replacement footprints, the frequencies of $\mathrm{V}_{\mathrm{H}}$ replacement products in $\mathrm{IgH}$ genes derived from $\mathcal{N} Z B / \mathcal{N} Z W, M R L /$ lpr, SLE1, SLE1/SLE3 and IgH genes encoding anti-DNA and ANA antibodies are significantly higher than that in the $B A L B / c$ mice $(p<0.05$, two tailed $C h i$-square test) (Fig. 2B); with considering the 3-mer $\mathrm{V}_{\mathrm{H}}$ replacement footprints, the frequencies of $\mathrm{V}_{\mathrm{H}}$ replacement products in $\mathrm{IgH}$ genes derived from $\mathcal{N} Z B$ / NZW, NZM2410, MRL/lpr, SLE1, SLE1/SLE3, NOD/NOR and IgH genes encoding auto antibodies, anti-DNA antibodies, and ANA antibodies are significantly higher than that in the $B A L B / c$ mice $(p<0.05$, two tailed $C h i$-square test) (Fig. 2C). Taken together, these results showed that $\mathrm{V}_{\mathrm{H}}$ replacement products are enriched in IgH genes derived from different strains of autoimmune prone mice and in IgH genes encoding autoantibodies.

\section{The Identified $V_{H}$ Replacement Footprints Preferentially Encode Charged Amino Acids}

Our previous analysis of the identified $\mathrm{V}_{\mathrm{H}}$ replacement products in human $\mathrm{IgH}$ genes showed that the $\mathrm{V}_{\mathrm{H}}$ replacement footprints preferentially encode charged amino acids into the IgH CDR3 regions [31]. Here, analysis of the identified $\mathrm{V}_{\mathrm{H}}$ replacement products from mouse $\mathrm{IgH}$ genes showed that $64 \%$ of the amino acids encoded by the identified $\mathrm{V}_{\mathrm{H}}$ replacement footprints contribute charged amino acids, including $\mathrm{K}, \mathrm{R}, \mathrm{D}, \mathrm{E}, \mathrm{N}$, and Q. Such frequency is significantly higher than the overall frequency of charged amino acids in the N1 regions $(p<0.0001)$ (Fig. 3A). Moreover, the frequencies of charged amino acids, including $\mathrm{E}, \mathrm{K}$, and $\mathrm{R}$, encoded by the identified $\mathrm{V}_{\mathrm{H}}$ replacement footprints are significantly higher than those encoded by the N1 regions of non- $\mathrm{V}_{\mathrm{H}}$ replacement products $(p<0.0001)$ (Fig. 3B). The preferential contribution of charged amino acids by the $\mathrm{V}_{\mathrm{H}}$ replacement footprints seems to be predetermined by the sequences at the $3^{\prime}$ end of $\mathrm{V}_{\mathrm{H}}$ germline genes following the cRSS sites. The frequencies of charged amino acids encoded by the $3^{\prime}$ ends of $\mathrm{V}_{\mathrm{H}}$ germline gene, including $\mathrm{K}, \mathrm{R}, \mathrm{D}, \mathrm{E}, \mathrm{N}$, and $\mathrm{Q}$ are significantly higher than those encoded by the $\mathrm{D}_{\mathrm{H}}$ germline genes $(p<0.0001)$ (Fig. 3C). In non-functional IgH genes, the identified $\mathrm{V}_{\mathrm{H}}$ replacement footprints also preferentially encode charged amino acids, although the usages of different charged residues are slightly different from those in the functional $\mathrm{V}_{\mathrm{H}}$ replacement
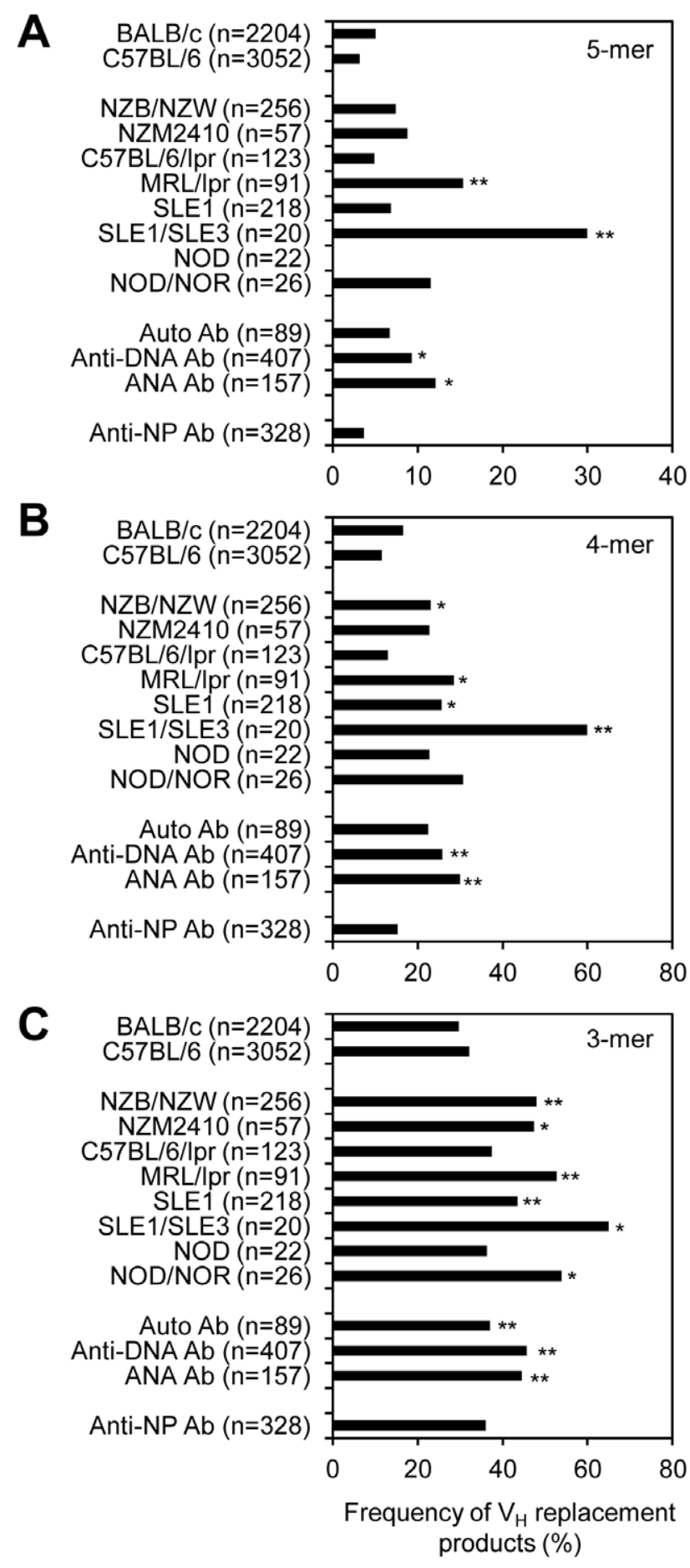

Figure 2. Enrichment of $V_{H}$ replacement products in IgH genes derived from different strains of autoimmune prone mice and IgH genes encoding autoantibodies. The frequencies of $V_{H}$ replacement products in $\mathrm{IgH}$ genes derived from different strains of mice were analyzed using the $\mathrm{V}_{\mathrm{H}} \mathrm{RFA}$ program based on the keyword linked to each IgH gene in the NCBI database. $V_{H}$ replacement products were assigned based on the identification of (A) 5-mer $V_{H}$ replacement footprints, (B) 4-mer $V_{H}$ replacement footprints, or (C) 3-mer $V_{H}$ replacement footprints within the $V_{H}-D_{H}$ junctions (N1 regions). The frequencies of $V_{H}$ replacement products in different subcategories were compared with that in the $B A L B / c$ mice. $n$, number of $\lg \mathrm{H}$ sequences in each subcategory. Statistical significance was determined using a twotailed Chi square test with Yate's correction. $p<0.05\left(^{*}\right)$ is considered 
significant and $p<0.0001\left(^{* *}\right)$ is considered extremely significant. The detailed sequence analysis and the identified $V_{H}$ replacement products with 5-mer $V_{H}$ replacement footprints correlating with keywords are included in Table S6.

doi:10.1371/journal.pone.0057877.g002

products (Fig. 3D). Such results are consistent with previous findings that the $\mathrm{V}_{\mathrm{H}}$ replacement footprints identified in human or mouse $\mathrm{V}_{\mathrm{H}}$ replacement products preferentially encoded charged residues $[31,39]$.

\section{The 3-mer $\mathrm{V}_{\mathrm{H}}$ Replacement Footprints are Less Likely Contribute Charged Amino Acids to the CDR3 Regions}

$\mathrm{V}_{\mathrm{H}}$ replacement was considered as a receptor editing process to change non-functional $\mathrm{IgH}$ rearrangements or IgH genes encoding autoantibodies [29,41]. Finding that the 5-mer $\mathrm{V}_{\mathrm{H}}$ replacement footprints preferentially encoded charged amino acids, especially $R$ and $K$ residues, is contrast to the original goal of $V_{H}$ replacement to eliminate autoreactive $\mathrm{IgH}$ genes. Because charged residues within the IgH CDR3 might contribute to autoreactivity. Interestingly, when we analyzed the amino acids encoded by the identified 3-mer $\mathrm{V}_{\mathrm{H}}$ replacement footprints, the usages of charged residues, including $\mathrm{R}, \mathrm{K}$, and $\mathrm{E}$, are significantly reduced; meantime, the usages of several neutral residues, including $\mathrm{H}, \mathrm{L}$, and $\mathrm{Y}$, are significantly increased (Fig. 4A). These results showed that shorter $\mathrm{V}_{\mathrm{H}}$ replacement footprints are less likely to encode charged residues.

\section{$\mathrm{V}_{\mathrm{H}}$ Replacement Products have Longer CDR3 Lengths}

During $\mathrm{V}_{\mathrm{H}}$ replacement products, a short stretch of nucleotides from previously rearranged $\mathrm{V}_{\mathrm{H}}$ genes were left within the newly generated $\mathrm{V}_{\mathrm{H}}-\mathrm{DJ}_{\mathrm{H}}$ junctions [31]. Comparison of the IgH CDR3 lengths of the identified $\mathrm{V}_{\mathrm{H}}$ replacement products showed that the average CDR3 length of $\mathrm{V}_{\mathrm{H}}$ replacement products with 5-mer footprints is significantly longer than that of $\mathrm{V}_{\mathrm{H}}$ replacement products with 3-mer footprints; the average CDR3 length of $\mathrm{V}_{\mathrm{H}}$ replacement products with 3-mer footprints is significantly longer than that of the total functional $\mathrm{IgH}$ genes in the NCBI database $(p<0.0001$, unpaired $t$ test) (Fig. 4B). These results indicate that elongation of IgH CDR3 region is one of the intrinsic features of $\mathrm{V}_{\mathrm{H}}$ replacement.

\section{Selection of $\mathrm{V}_{\mathrm{H}}$ Replacement Footprints Encoding Positively Charged Residues in Autoantibodies}

The preferential contribution of charged amino acids by $\mathrm{V}_{\mathrm{H}}$ replacement footprints is likely predetermined by the $3^{\prime}$ end sequences of $\mathrm{V}_{\mathrm{H}}$ germline genes. Based on the $3^{\prime}$ end sequences of $\mathrm{V}_{\mathrm{H}}$ germline genes, $\mathrm{V}_{\mathrm{H}}$ replacement footprints can contribute almost equal numbers of positively or negatively charged residues (Fig. 5A). Indeed, in the identified $\mathrm{V}_{\mathrm{H}}$ replacement products from $\mathrm{IgH}$ genes derived from $B A L B / c$ or $C 57 B L / 6$ mice, the frequencies of positively and negatively charged amino acids encoded by the $\mathrm{V}_{\mathrm{H}}$ replacement products are similar (Fig. 5A). However, in the identified $\mathrm{V}_{\mathrm{H}}$ replacement products in $\mathrm{IgH}$ genes from autoimmune prone mice, including $M R L / l p r$ and Sle1/Sle3 mice, the frequencies of positively charged residues encoded by the $V_{H}$ replacement footprints are significantly higher than that in the control mice. Meantime, the frequencies of negatively charged residues encoded by the $\mathrm{V}_{\mathrm{H}}$ replacement footprints are significantly lower than that in the control mice (Fig. 5A). The frequencies of negatively charged residues encoded by the identified $\mathrm{V}_{\mathrm{H}}$ replacement footprints are significantly lower in $\mathrm{IgH}$ genes derived from $\mathrm{C} 56 \mathrm{BL} / 6 / \mathrm{lpr}$ mice and in $\mathrm{IgH}$ genes encoding anti-DNA or ANA antibodies (Fig. 5A). Detailed analysis of the functional versus non-functional $\mathrm{IgH}$ genes derived from $M R L / l p r$ mice showed that the frequencies of positively charged residues encoded by the identified $\mathrm{V}_{\mathrm{H}}$ replacement footprints were elevated in functional but not in non-functional $\mathrm{IgH}$ genes (Fig. 5B). These results indicate that the positively charged residues encoded by $\mathrm{V}_{\mathrm{H}}$ replacement products were positively selected in these autoimmune prone mice.

\section{The Identified $\mathrm{V}_{\mathrm{H}}$ Replacement Products are Mutated}

The accumulation of $\mathrm{V}_{\mathrm{H}}$ replacement products in $\mathrm{IgH}$ genes derived from different strains of autoimmune prone mice and $\mathrm{IgH}$ genes encoding different autoantibodies suggested that $\mathrm{V}_{\mathrm{H}}$ replacement products contribute to the generation of autoantibodies in mice. Analyses of the mutation status of these identified $V_{H}$ replacement products showed that the enriched $\mathrm{V}_{\mathrm{H}}$ replacement products in autoimmune prone mice or IgH genes encoding antiDNA or ANA autoantibodies are mutated (Fig. 5C), indicating that these $\mathrm{V}_{\mathrm{H}}$ replacement products are positively selected in these autoimmune prone mice.

\section{Discussion}

In the current report, we analyzed 17,179 mouse IgH gene sequences available from the NCBI database and provided a comprehensive view of the $\mathrm{V}_{\mathrm{H}}, \mathrm{D}_{\mathrm{H}}$, and $\mathrm{J}_{\mathrm{H}}$ gene usages of these mouse $\mathrm{IgH}$ genes. Based on the identification of the pentameric $\mathrm{V}_{\mathrm{H}}$ replacement footprints in the $\mathrm{N} 1$ regions, we estimated that the frequency of $\mathrm{V}_{\mathrm{H}}$ replacement products in the 11309 unique mouse $\operatorname{IgH}$ gene sequences with identifiable $\mathrm{D}_{\mathrm{H}}$ genes is $5.29 \%$. Such result indicates a significant contribution of $\mathrm{V}_{\mathrm{H}}$ replacement products to the diversification of murine antibody repertoire. This result is consistent with the previously estimated frequencies of $\mathrm{V}_{\mathrm{H}}$ replacement products in human and mouse $\mathrm{IgH}$ genes [31,39]. It should be pointed out that such estimation is based on the identification of $\mathrm{V}_{\mathrm{H}}$ replacement footprints with a minimal length of 5 nucleotides. In comparison to human $\mathrm{V}_{\mathrm{H}}$ germline genes, many mouse $\mathrm{V}_{\mathrm{H}}$ germline genes have fewer nucleotides following the cRSS sites. Out of the 150 functional mouse $\mathrm{V}_{\mathrm{H}}$ germline genes with cRSS sites, 60 of them have only 5 nucleotides following the cRSS sites. If there is any exo-nuclease activity to remove one nucleotide at either the $3^{\prime}$ or the $5^{\prime}$ end of the $V_{H}$ replacement footprint during primary $V_{H}$ to $\mathrm{DJ}_{\mathrm{H}}$ recombination or $\mathrm{V}_{\mathrm{H}}$ replacement recombination, respectively, the remaining $\mathrm{V}_{\mathrm{H}}$ replacement footprints will have less than 5 nucleotides and cannot be identified from this analysis. Based on this consideration, assigning $\mathrm{V}_{\mathrm{H}}$ replacement footprints with 4 or 3 nucleotides might be a reasonable and accurate method to identify potential $\mathrm{V}_{\mathrm{H}}$ replacement products in mouse $\mathrm{IgH}$ genes. If we consider the 4- or 3-mer $\mathrm{V}_{\mathrm{H}}$ replacement footprints at the $\mathrm{N} 1$ regions to assign $V_{H}$ replacement products, the frequencies of $V_{H}$ replacement products in the mouse $\mathrm{IgH}$ gene sequences should be $16 \%$ or $32 \%$, respectively.

It has been shown previously that in mice carrying two nonfunctional alleles of $\mathrm{IgH}$ genes, $\mathrm{V}_{\mathrm{H}}$ replacement occurs efficiently to generate almost normal number of $\mathrm{B}$ cells with a diversified repertoire [32,33]. All these functional $\mathrm{IgH}$ genes in this mouse are generated through $\mathrm{V}_{\mathrm{H}}$ replacement. However, only about $20 \%$ of the $\mathrm{IgH}$ gene sequences contain potential $\mathrm{V}_{\mathrm{H}}$ replacement footprints $(>3$ mer). The other $80 \%$ of $\mathrm{IgH}$ gene sequences have no identifiable $\mathrm{V}_{\mathrm{H}}$ replacement footprints [32,33]. This result indicates that most of the $\mathrm{V}_{\mathrm{H}}$ replacement footprints are deleted during $\mathrm{V}_{\mathrm{H}}$ replacement recombination. Thus, even if using the minimal length of $\mathrm{V}_{\mathrm{H}}$ replacement footprints with 4 or 3 

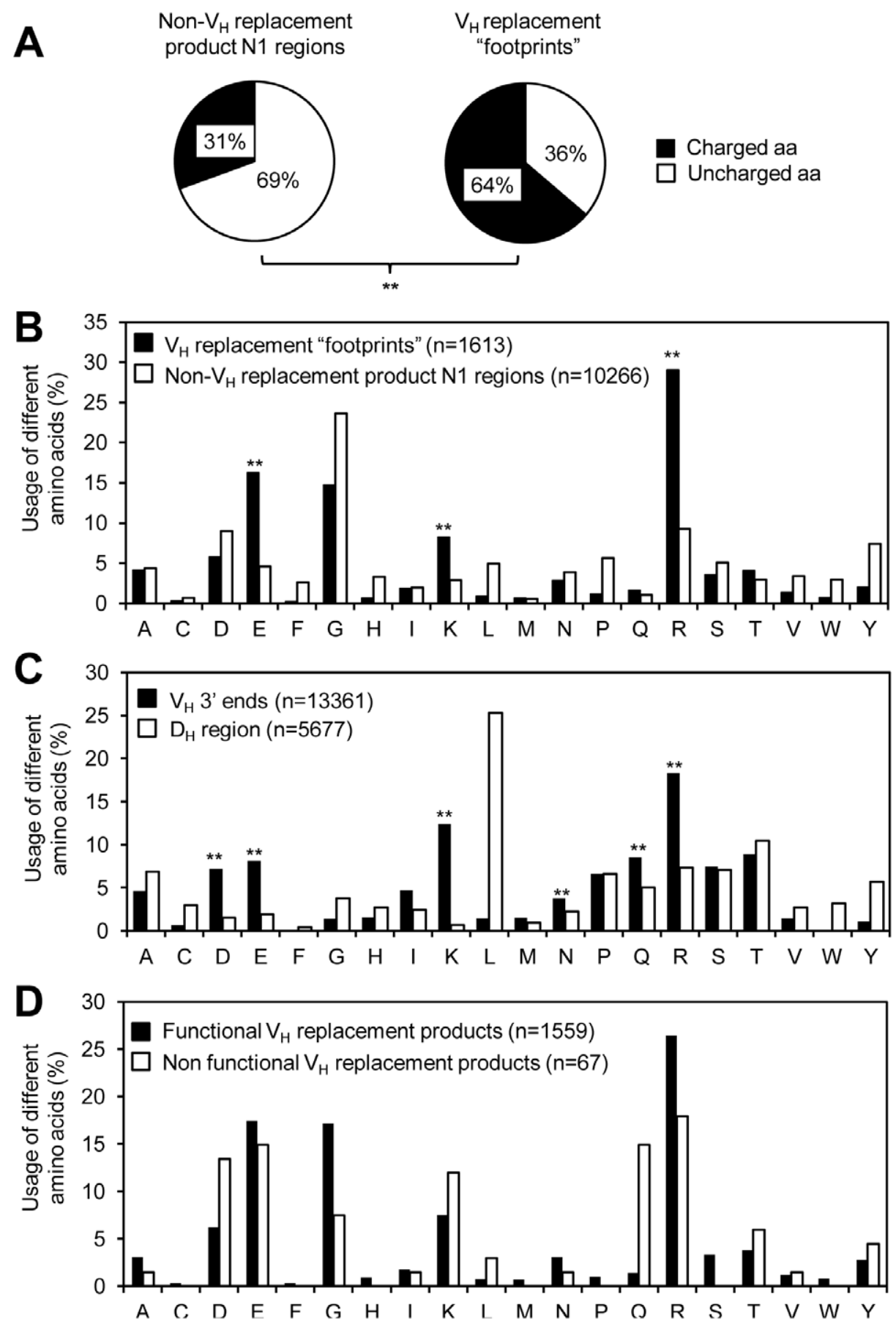

Figure 3. VH replacement footprints preferentially contribute charged amino acids to the CDR3 regions. (A) The frequencies of charged amino acids encoded by the identified pentameric $V_{H}$ replacement footprints or the $\mathrm{N} 1$ regions of non- $\mathrm{V}_{\mathrm{H}}$ replacement products were compared. Detailed amino acid sequences of the IgH CDR3 regions are listed in Table S6. (B) The frequencies of individual amino acid encoded by the identified $V_{H}$ replacement footprints or the $\mathrm{N} 1$ regions of non- $\mathrm{V}_{H}$ replacement products were compared. $n$, amino acids encoded by the identified $V_{H}$ replacement footprints or the $\mathrm{N} 1$ regions of non- $\mathrm{V}_{\mathrm{H}}$ replacement products. (C) The frequencies of individual amino acid encoded by the $3^{\prime}$ end of $\mathrm{V}_{\mathrm{H}}$ germline genes and $D_{H}$ regions were compared. $n$, amino acids encoded by the $V_{H}$ gene $3^{\prime}$ ends or $D_{H}$ regions. (D) Usages of different amino acids encoded by the identified $V_{H}$ replacement footprints in functional $V_{H}$ replacement products and non-functional $V_{H}$ replacement products. $n$, amino acids encoded by the identified $V_{H}$ replacement footprints. Statistical significance was determined using a two-tailed Chi square test with Yate's correction. $n$, number of amino acid residues encoded by indicated sequences. $p<0.05{ }^{*}$ ) is considered significant and $p<0.0001(* *)$ is considered extremely significant.

doi:10.1371/journal.pone.0057877.g003

nucleotides, we may still under-estimate the actual frequency of $\mathrm{V}_{\mathrm{H}}$ replacement products in the murine $\mathrm{IgH}$ repertoire. Theoretically, $66.7 \%$ of the $\mathrm{IgH}$ rearrangements generated during $\mathrm{V}(\mathrm{D}) \mathrm{J}$ recombination will be out of reading frame and cannot produce functional $\mathrm{IgH}$ proteins; about $44 \%$ of the pro B cells undergoing $\mathrm{V}(\mathrm{D}) \mathrm{J}$ recombination should carry non-functional rearrangements 

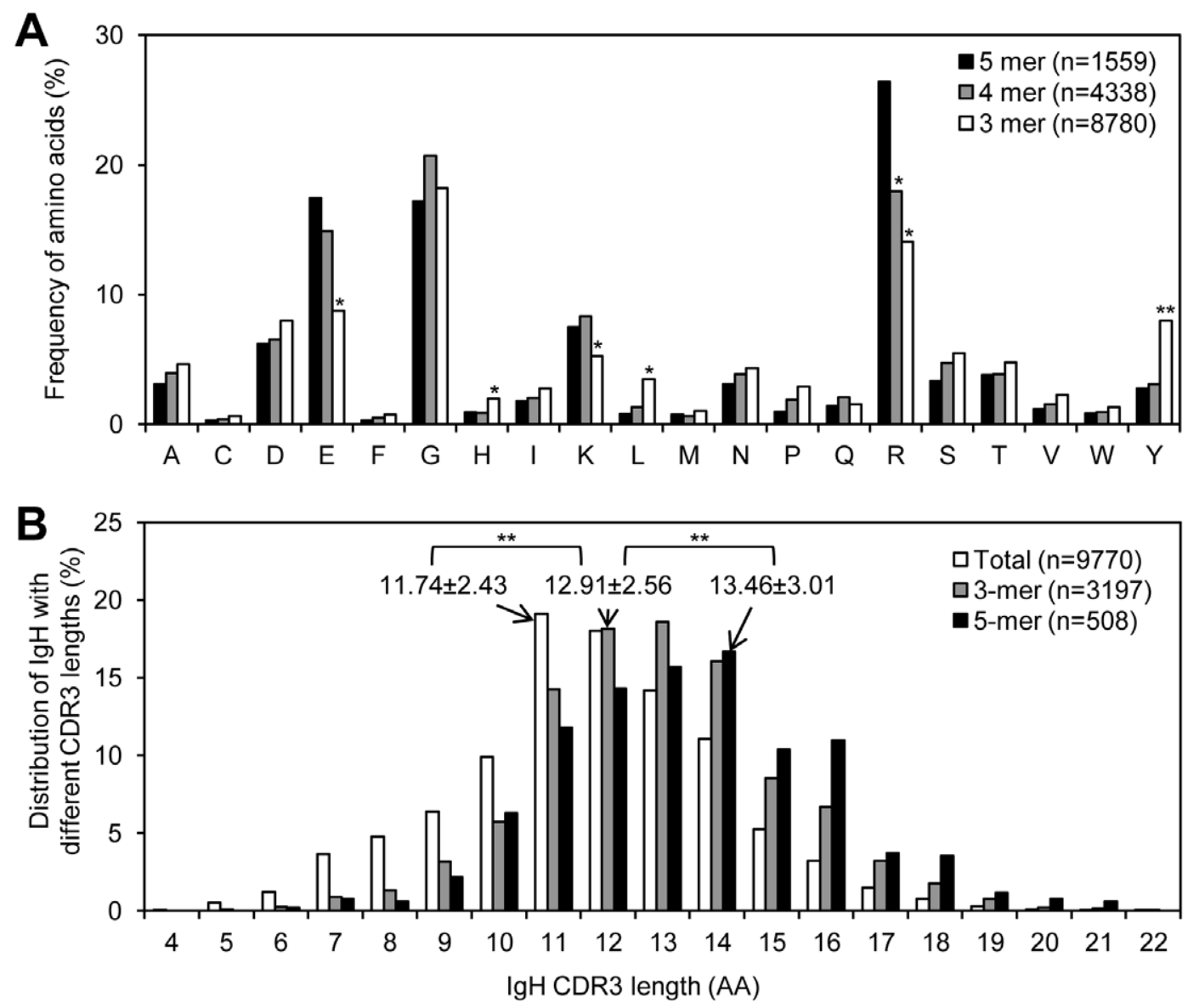

Figure 4. Comparison of the amino acids encoded by $V_{H}$ replacement footprints and the IgH CDR3 lengths of $V_{H}$ replacement products. (A) The usages of different amino acids encoded by $V_{H}$ replacement footprints with 5,4 , or 3 nucleotides were compared. $n$, number of amino acid residues encoded by the identified $V_{H}$ replacement footprints with different lengths. Statistical significance was determined using a twotailed Chi square test with Yate's correction. $p<0.05\left(^{*}\right)$ is considered significant and $p<0.0001\left(^{* *}\right)$ is considered extremely significant. (B) Comparison of the IgH CDR3 lengths of $V_{H}$ replacement products containing the 5-mer or the 3-mer $V_{H}$ replacement products with the CDR3 length of the total functional IgH genes. $n$, number of $\mathrm{IgH}$ sequences or $\mathrm{V}_{\mathrm{H}}$ replacement products with 3- or 5-mer $\mathrm{V}_{\mathrm{H}}$ replacement footprints. Statistical significance was determined using unpaired $t$ test. $p<0.05\left(^{*}\right)$ is considered significant and $p<0.0001\left(^{* *}\right)$ is considered extremely significant.

doi:10.1371/journal.pone.0057877.g004

on both $\mathrm{IgH}$ alleles. If $\mathrm{V}_{\mathrm{H}}$ replacement can efficiently rescue these pro B cells, at least $44 \%$ of the expressed IgH genes should be generated by $\mathrm{V}_{\mathrm{H}}$ replacement.

We should also point out that this sequence analysis based approach in identification of $\mathrm{V}_{\mathrm{H}}$ replacement footprints may have false positive calls. Theoretically, there are no $\mathrm{V}_{\mathrm{H}}$ replacement footprints in the $\mathrm{N} 2$ regions. In some of the $\mathrm{IgH}$ sequences, we identified similar 3, 4, or 5 mer $\mathrm{V}_{\mathrm{H}}$ replacement footprint motifs in the N2 regions, although the frequencies of such motifs in the N2 regions are significantly lower than those in the $\mathrm{N} 1$ regions. The presence of such $\mathrm{V}_{\mathrm{H}}$ replacement footprint motifs in the $\mathrm{N} 2$ regions could be due to random nucleotide addition during $\mathrm{V}(\mathrm{D}) \mathrm{J}$ recombination. In this regard, a low frequency of identified footprints might be false positive.

If we use the 5-mer $\mathrm{V}_{\mathrm{H}}$ replacement footprints to assign $\mathrm{V}_{\mathrm{H}}$ replacement products, the frequencies of $\mathrm{V}_{\mathrm{H}}$ replacement products in $\mathrm{IgH}$ genes derived from $B A L B / C$ or $C 57 B L / 6$ mice are about $5 \%$ or $3.2 \%$, respectively, which may represent the basal level of $\mathrm{V}_{\mathrm{H}}$ replacement product in these two strains of mice. Interestingly, the frequencies of $\mathrm{V}_{\mathrm{H}}$ replacement products are significantly elevated in $\mathrm{IgH}$ genes derived from different strains of autoimmune prone mice, including $M R L / L p r$ and Sle1/Sle3 mice. It has been well demonstrated that these mice spontaneously produce anti-DNA or anti-ANA antibodies and develop lupus like symptom [42-49]. Indeed, $\mathrm{V}_{\mathrm{H}}$ replacement products are significantly elevated in IgH genes encoding anti-DNA antibodies or ANA autoantibodies derived from mice with lupus glomerular nephritis. These results suggested a potential contribution of $V_{H}$ replacement products to the generation of autoantibodies. When we consider the 4- or 3-mer $\mathrm{V}_{\mathrm{H}}$ replacement footprints to assign $\mathrm{V}_{\mathrm{H}}$ replacement products, the frequencies of $\mathrm{V}_{\mathrm{H}}$ replacement products are elevated in all the sub-categories of $\mathrm{IgH}$ genes. Nevertheless, the frequencies of $\mathrm{V}_{\mathrm{H}}$ replacement products in $\mathrm{IgH}$ genes derived from different strains of autoimmune prone mice and IgH genes encoding anti-DNA and ANA antibodies are significantly higher than that in the BALB/c mice.

Due to the location of the cRSS, $\mathrm{V}_{\mathrm{H}}$ replacement will leave a short stretch of $\mathrm{V}_{\mathrm{H}}$ replacement footprints to elongate the $\mathrm{IgH}$ CDR3 region [31,41]. Strikingly, the identified pentameric $\mathrm{V}_{\mathrm{H}}$ replacement footprints preferentially encode charged amino acids in the newly formed CDR3 regions. Such features are commonly found in $\mathrm{V}_{\mathrm{H}}$ replacement products identified from human and mouse $\mathrm{IgH}$ genes [31,39] and highly conserved in all the jawed vertebrates [50]. IgH genes with long CDR3 and charged residues 

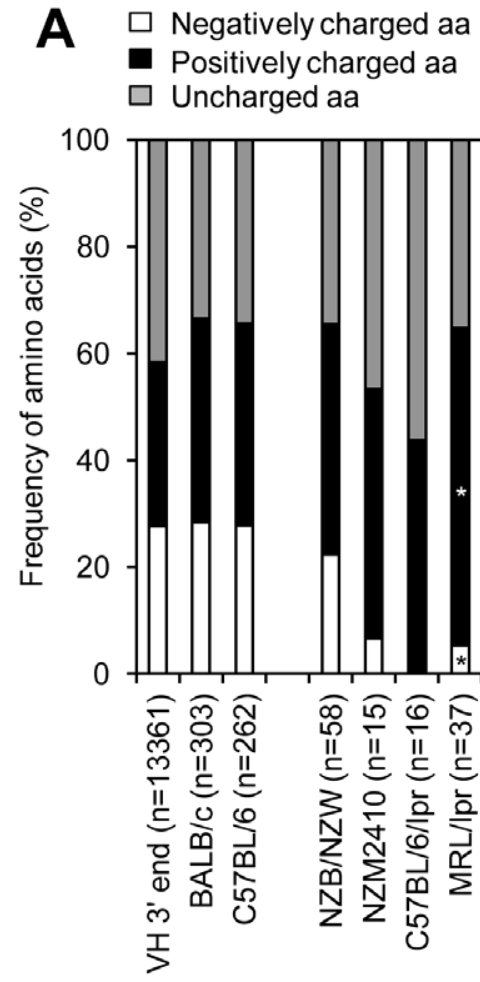
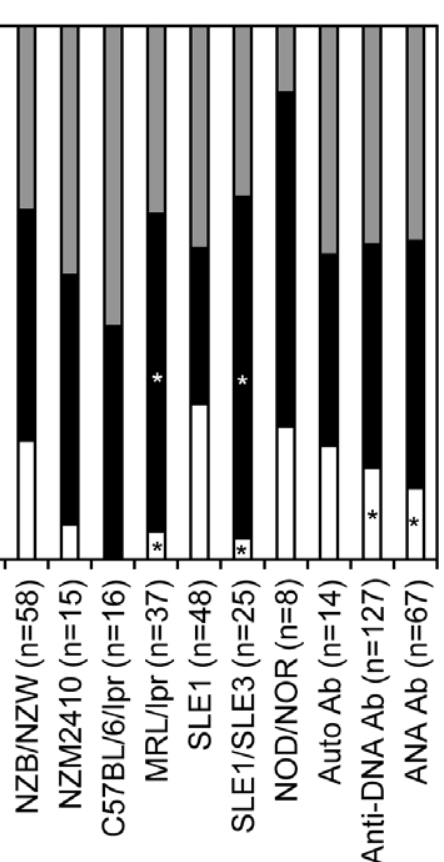

B

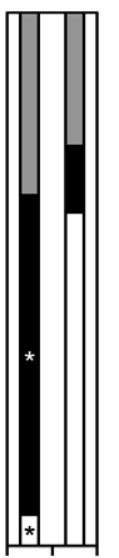

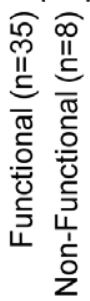
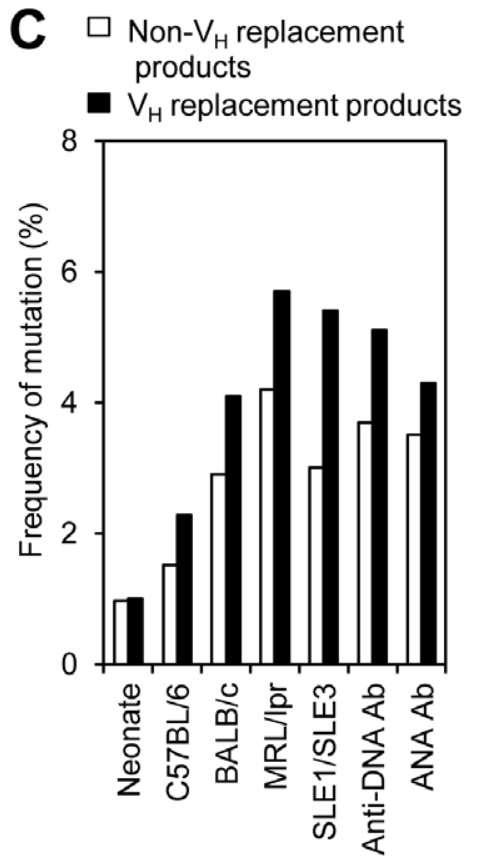

Figure 5. The enriched $\mathrm{V}_{\mathrm{H}}$ replacement products identified in different strains of autoimmune prone mice or lgH genes encoding autoantibodies have been positively selected during autoimmune responses. (A) Analysis of the frequencies of positively charged versus negatively charged amino acids encoded by the $3^{\prime}$ end $V_{H}$ genes and the identified $V_{H}$ replacement footprints from different strains of mice or IgH genes encoding autoantibodies. Statistical significance was determined using a two-tailed Chi square test with Yate's correction. $p<0.05(*)$ is considered significant. (B) Comparison of the amino acids encoded by the identified $\mathrm{V}_{\mathrm{H}}$ replacement footprints in MRL/lpr mice. $n$, numbers of amino acids encoded by the identified $V_{H}$ replacement footprints. (C) Mutation status analysis of identified $V_{H}$ replacement products and non- $V_{H}$ replacement products from different subgroups of $\mathrm{IgH}$ genes.

doi:10.1371/journal.pone.0057877.g005

are frequently encoding autoantibodies or anti-viral antibodies [51]. Here, our results showed that the frequencies of $\mathrm{V}_{\mathrm{H}}$ replacement products are significantly elevated in $\mathrm{IgH}$ genes encoding anti-DNA and ANA autoantibodies in mouse. Theoretically, the $\mathrm{V}_{\mathrm{H}}$ replacement footprints can encode either positively or negatively charged residues. Analysis of the amino acids encoded by the identified $\mathrm{V}_{\mathrm{H}}$ replacement products from different strains of autoimmune prone mice and $\operatorname{IgH}$ genes encoding autoantibodies showed that the frequencies of positively charged residues encoded by $\mathrm{V}_{\mathrm{H}}$ replacement footprints are significantly elevated; while the frequencies of negatively charged residues encoded by $\mathrm{V}_{\mathrm{H}}$ replacement footprints are significantly reduced. Previous studies have shown that positively charged residue like Arg within the IgH CDR3 is critical for DNA binding [52-54]. These results suggested that the identified $\mathrm{V}_{\mathrm{H}}$ replacement products from autoimmune prone mice have been positively selected. Such notion is also supported by the accumulated mutations in these identified $\mathrm{V}_{\mathrm{H}}$ replacement products.

$\mathrm{V}_{\mathrm{H}}$ replacement was originally recognized as a receptor editing process to change either non-functional $\mathrm{IgH}$ genes or IgH genes encoding autoreactive antibodies [20,55]. The enrichment of $\mathrm{V}_{\mathrm{H}}$ replacement products in $\mathrm{IgH}$ genes from different strains of autoimmune prone mice and in IgH genes encoding autoantibodies are surprising findings from this study. Currently, it is not clear why $\mathrm{V}_{\mathrm{H}}$ replacement products are accumulated in autoimmune prone mice. Like any recombination process, $\mathrm{V}_{\mathrm{H}}$ replacement is a random process that can generate non-functional $\mathrm{IgH}$ genes or $\mathrm{IgH}$ genes encoding autoreactive antibodies.
Previous studies have shown that $\mathrm{V}_{\mathrm{H}}$ replacement products generated through replacing the knocked-in anti-DNA IgH genes can produce high affinity anti-DNA antibodies during chronic graft-versus-host $(\mathrm{cGVH})$ response [56]. Theoretically, after $\mathrm{V}_{\mathrm{H}}$ replacement recombination, the newly generated $\mathrm{IgH}$ genes should be subjected to strict negative selection again to eliminate B cells expressing autoreactive BCRs. The observed accumulation of $\mathrm{V}_{\mathrm{H}}$ replacement products in autoimmune prone mice could be due to the defective negative selection processes in these mice. In autoimmune prone mice, the newly generated $\mathrm{V}_{\mathrm{H}}$ replacement products encoding autoreactive antibodies cannot be efficiently eliminated, but are rather positively selected and contribute to the generation of autoantibodies. To this extend, the different strains of autoimmune prone mice will be excellent experimental models to dissect how the $\mathrm{V}_{\mathrm{H}}$ replacement products are selected and enriched during early B cell development.

Our analyses of the amino acid residues encoded by the identified $\mathrm{V}_{\mathrm{H}}$ replacement footprints also uncovered an interesting finding that short $\mathrm{V}_{\mathrm{H}}$ replacement footprints, especially the 3-mer footprints, encode less charged residues. These results suggested that if the $\mathrm{V}_{\mathrm{H}}$ replacement footprints were trimmed down to 3-mer during either primary or secondary recombination, they will be less likely to contribute charged amino acids into the IgH CDR3 regions. Given the fact that $33.55 \%$ of $\mathrm{IgH}$ genes contain 3-mer $\mathrm{V}_{\mathrm{H}}$ replacement footprints at their $\mathrm{Nl}$ regions, it is reasonable to conclude that the majority of these $\mathrm{V}_{\mathrm{H}}$ replacement products successfully edited the $\mathrm{IgH}$ genes without introducing of extra charged residues into the newly formed CDR3 regions. The 
observed accumulation of $\mathrm{V}_{\mathrm{H}}$ replacement products based on the identification of 5-mer footprints in the $\mathrm{N} 1$ regions in $\mathrm{IgH}$ genes derived from autoimmune prone mice may represent the failed $\mathrm{V}_{\mathrm{H}}$ replacement attempts either due to defects in negative selection or defects in trimming down the $\mathrm{V}_{\mathrm{H}}$ replacement footprints during primary or secondary recombination. Such findings raised several interesting questions that require further studies.

In conclusion, analysis of large number of mouse $\mathrm{IgH}$ gene sequences from the NCBI database provides a comprehensive view of the $\mathrm{IgH}$ repertoire of the available mouse $\mathrm{IgH}$ genes in the NCBI database and reveals a significant contribution of $\mathrm{V}_{\mathrm{H}}$ replacement products to the diversification of mouse $\mathrm{IgH}$ repertoire. Identification of enriched $\mathrm{V}_{\mathrm{H}}$ replacement products in IgH genes derived from different strains of autoimmune prone mice and $\operatorname{IgH}$ genes encoding autoantibodies indicated that abnormal regulation of $\mathrm{V}_{\mathrm{H}}$ replacement may contribute to the generation of autoreactive antibodies.

\section{Materials and Methods}

\section{Mouse IgH Sequences}

Entrez IDs of mouse IgH sequences were provided by Igblast (http://www.ncbi.nlm.nih.gov/projects/igblast/) on May 07, 2011, which were used to download GenBank records of the sequences from NCBI. There were total 17,179 mouse IgH gene sequences retrieved at that time. The IDs of these $\operatorname{IgH}$ genes and their $\mathrm{V}_{\mathrm{H}}, \mathrm{D}_{\mathrm{H}}$, and $\mathrm{J}_{\mathrm{H}}$ gene assignments are included in Table $\mathrm{S} 1$. After assignment of the potential germline $\mathrm{V}_{\mathrm{H}}, \mathrm{D}_{\mathrm{H}}, \mathrm{J}_{\mathrm{H}}$ genes, clonally redundant sequences were stripped out based on their identical CDR3 regions. The resulting 11,308 unique sequences were further analyzed. Clonally related sequences with mutations within their CDR3 regions still remain. The 17179 mouse IgH sequences were derived from 861 published studies (Table S2). There were 1, 2, 4, 4, and 6 publications that contributed more than 500, 400-499, 300-399,200-299, and 100-199 sequences, respectively; 127 publications contributed 11-99 sequences; 717 publications contributed 10 or less than 10 sequences.

\section{The $V_{H} R F A$ Program}

We developed a Java-based $\mathrm{V}_{\mathrm{H}} \mathrm{RFA}$ program to incorporate assignments of the $\mathrm{V}_{\mathrm{H}}, \mathrm{D}_{\mathrm{H}}$, and $\mathrm{J}_{\mathrm{H}}$ germline gene segments using the V-QUEST program (http://www.imgt.org/IMGT_vquest), identification of $\mathrm{V}_{\mathrm{H}}$ replacement footprints with different lengths, analysis of amino acids encoded by the identified $\mathrm{V}_{\mathrm{H}}$ replacement footprints, calculation of the amino acid usage encoded by the identified $\mathrm{V}_{\mathrm{H}}$ replacement footprints, and correlation of the identified $\mathrm{V}_{\mathrm{H}}$ replacement products with different keywords and publications associated with the sequences in the NCBI database.

\section{$\mathrm{V}_{\mathrm{H}}, \mathrm{D}_{\mathrm{H}}$, and $\mathrm{J}_{\mathrm{H}}$ Germline Gene Assignment}

Mouse IgH sequences in the GenBank format were converted to FASTA format and submitted to IMGT/V-QUEST (http:// www.imgt.org/IMGT_vquest/share/textes/) for assign potential germline $\mathrm{V}_{\mathrm{H}}, \mathrm{D}_{\mathrm{H}}, \mathrm{J}_{\mathrm{H}}$ genes, allowing 1 mutation at the $3^{\prime}$ end of $\mathrm{V}_{\mathrm{H}}$ genes and at the $5^{\prime}$ end of $\mathrm{J}_{\mathrm{H}}$ genes. All the $\mathrm{IgH}$ gene sequences were analyzed in batches containing 50 sequences each batch and the results were downloaded to a local computer as Excel files. These processes were conducted using the $\mathrm{V}_{\mathrm{H}} \mathrm{RFA}$ program.

\section{Identification of $\mathrm{V}_{\mathrm{H}}$ Replacement Footprint}

All the rest steps were conducted on a local computer by the $\mathrm{V}_{\mathrm{H}}$ RFA program. First, a library file was generated, which contains all the potential $\mathrm{V}_{\mathrm{H}}$ replacement footprints derived from functional $\mathrm{V}_{\mathrm{H}}$ germline reference genes from the IMGT database (Table S3). Basically, the 3' end segments following the cRSS sites from functional mouse $\mathrm{V}_{\mathrm{H}}$ genes were sliced into different groups with 3, 4, 5, 6, 7, 8, 9, 10, and 11 nucleotides in length (Table S4). The $\mathrm{V}_{\mathrm{H}}$ RFA program will use this library to search the $\mathrm{Nl}\left(\mathrm{V}_{\mathrm{H}^{-}}\right.$ $\mathrm{D}_{\mathrm{H}}$ junction $(\mathrm{N} 1)$ or $\mathrm{D}_{\mathrm{H}}-\mathrm{J}_{\mathrm{H}}$ junction ( $\mathrm{N} 2$, as negative control) regions of the $\mathrm{IgH}$ genes to identify matched footprint motifs. For each $\mathrm{IgH}$ gene, the $\mathrm{V}_{\mathrm{H}} \mathrm{RFA}$ program started by searching the longest footprint motifs $(11 \mathrm{mer})$ from the $5^{\prime}$ to $3^{\prime}$ of the DNA sequences and then goes to search footprints with one nucleotide shorter. The identified footprints were listed if it does not overlap with any previously identified footprint within this region. For examples, the end results of footprint analyses of with specified 5 mer included all the footprints with 5, 6, 7, 8, 9, 10, and 11 mer from the $\mathrm{V}_{\mathrm{H}}$ replacement footprint library. The end result was exported as a CVS file that contains the gene ID, functionality, $\mathrm{V}_{\mathrm{H}}, \mathrm{D}_{\mathrm{H}}, \mathrm{J}_{\mathrm{H}}$ gene assignment, $\mathrm{V}_{\mathrm{H}}$ replacement footprint in $\mathrm{Nl}(\mathrm{N} l$ signatures) or $\mathrm{N} 2$ (N2 signatures), together with other information from the original Excel file provided by the IMGT V-QUEST program. The identified footprints were shown in parenthesis within the $\mathrm{N} 1$ or $\mathrm{N} 2$ region sequences.

\section{Analysis of the Amino Acid Encoded by $V_{H}$ Replacement Footprints, Keyword and Publication Linked to Each Gene, and Mutation}

After identification of the $\mathrm{V}_{\mathrm{H}}$ replacement footprints within the $\mathrm{N} 1$ regions, the $\mathrm{V}_{\mathrm{H}} \mathrm{RFA}$ program further analyzed the amino acids encoded by the $\mathrm{V}_{\mathrm{H}}$ replacement footprints and the usages of different amino acid. Each result was exported as an individual Excel file.

The $\mathrm{V}_{\mathrm{H}} \mathrm{RFA}$ program can also analyze the original GenBank file to correlate the keywords and publication information with each $\mathrm{IgH}$ gene sequence. Basically, the $\mathrm{V}_{\mathrm{H}} \mathrm{RFA}$ program parses the source GenBank file for keywords in the KEYWORDS and FEATURES sections of each entry sequence and output the keyword list in correlation with the sequence IDs, VDJ assignments, N1 footprints, and N2 footprints. Through this analysis, we can determine the distribution of $\mathrm{V}_{\mathrm{H}}$ replacement products in different diseases.

For mutation analysis, the $\mathrm{V}_{\mathrm{H}} \mathrm{RFA}$ program only calculated the mutation rate of $\operatorname{IgH} \mathrm{V}_{\mathrm{H}}$ genes with $>80 \%$ similarities to the assigned germline $\mathrm{V}_{\mathrm{H}}$ genes.

\section{Statistical Analysis}

Statistical significance was determined by using either the two tailed Chi-square test with Yates' correction or non paired student $t$ test. Significant difference was determined if the $p$ value $<0.05$.

\section{Supporting Information}

Table S1 Analyses of mouse IgH genes and identification of $\mathrm{VH}$ replacement products.

(XLSX)

Table S2 Number of sequences from each publication. (XLSX)

Table S3 Mouse VH genes containing the TACTGTG cRSS. (DOCX)

Table S4 Potential mouse $V_{H}$ replacement footprint motifs with different length.

(DOCX)

Table S5 Identification of 4-mer $V_{H}$ replacement footprint motifs in mouse IgH sequences.

(DOCX) 
Table S6 Identification of $\mathrm{V}_{\mathrm{H}}$ replacement products in $\mathrm{IgH}$ genes correlating with different keywords. (DOCX)

\section{References}

1. Schatz DG, Baltimore D (1988) Stable expression of immunoglobulin gene $\mathrm{V}(\mathrm{D}) \mathrm{J}$ recombinase activity by gene transfer into $3 \mathrm{~T} 3$ fibroblasts. Cell 53: 107115

2. Schatz DG, Oettinger MA, Baltimore D (1989) The V(D)J recombination activating gene, RAG-1. Cell 59: 1035-1048.

3. Oettinger MA, Schatz DG, Gorka C, Baltimore D (1990) RAG-1 and RAG-2, adjacent genes that synergistically activate $\mathrm{V}(\mathrm{D}) \mathrm{J}$ recombination. Science 248 : 1517-1523.

4. Bassing CH, Swat W, Alt FW (2002) The mechanism and regulation of chromosomal V(D) J recombination. Cell 109: S45-S55.

5. Jung D, Giallourakis C, Mostoslavsky R, Alt FW (2006) Mechanism and control of $\mathrm{V}(\mathrm{D}) \mathrm{J}$ recombination at the immunoglobulin heavy chain locus. Annu Rev Immunol 24: 541-570.

6. Lewis SM (1994) The mechanism of $\mathrm{V}(\mathrm{D}) \mathrm{J}$ joining: lessons from molecular, immunological, and comparative analyses. Adv Immunol 56: 27-150.

7. Schatz DG, Swanson PC (2011) V(D)J recombination: mechanisms of initiation. Annu Rev Genet 45: 167-202.

8. Ramsden DA, Baetz K, Wu GE (1994) Conservation of sequence in recombination signal sequence spacers. Nucleic Acids Res 22: 1785-1796.

9. Swanson PC, Desiderio S (1998) V(D)J recombination signal recognition: distinct, overlapping DNA-protein contacts in complexes containing RAG1 with and without RAG2. Immunity 9: 115-125.

10. Karasuyama H, Kudo A, Melchers F (1990) The proteins encoded by the VpreB and lambda 5 pre-B cell-specific genes can associate with each other and with mu heavy chain. J Exp Med 172: 969-972.

11. Karasuyama H, Rolink A, Melchers F (1993) A complex of glycoproteins is associated with $\mathrm{VpreB} / \mathrm{lambda} 5$ surrogate light chain on the surface of mu heavy chain-negative early precursor B cell lines. J Exp Med 178: 469-478.

12. Karasuyama H, Rolink A, Shinkai Y, Young F, Alt FW, et al. (1994) The expression of Vpre-B/lambda 5 surrogate light chain in early bone marrow precursor B cells of normal and B cell-deficient mutant mice. Cell 77: 133-143.

13. Lassoued K, Nunez CA, Billips L, Kubagawa H, Monteiro RC, et al. (1993) Expression of surrogate light chain receptors is restricted to a late stage in pre-B cell differentiation. Cell 73: 73-86.

14. Burrows PD, Stephan RP, Wang YH, Lassoued K, Zhang Z, et al. (2002) The transient expression of pre-B cell receptors governs $\mathrm{B}$ cell development. Semin Immunol 14: 343-349.

15. Karasuyama H, Nakamura T, Nagata K, Kuramochi T, Kitamura F, et al. (1997) The roles of preB cell receptor in early B cell development and its signal transduction. Immunol Cell Biol 75: 209-216.

16. Jung D, Alt FW (2004) Unraveling V(D)J recombination: insights into gene regulation. Cell 116: 299-311.

17. Burrows PD, Cooper MD (1997) B cell development and differentiation. Current Opin Immunol 9: 239-244.

18. Nemazee D, Weigert M (2000) Revising B cell receptors. J Exp Med 191: 18131817.

19. Meffre E, Casellas R, Nussenzweig MC (2000) Antibody regulation of B cell development. Nature Immunol 1: 379-385.

20. Zhang $Z$ (2007) $V_{H}$ replacement in mice and humans. Trends Immunol 28: $132-137$.

21. Gay D, Saunders T, Camper S, Weigert M (1993) Receptor editing: an approach by autoreactive B cells to escape tolerance. J Exp Med 177: 999-1008.

22. Tiegs SL, Russell DM, Nemazee D (1993) Receptor editing in self-reactive bone marrow B cells. J Exp Med 177: 1009-1020.

23. Radic M, Zouali M (1996) Receptor editing, immune diversification and selftolerance. Immunity 5: 505-511.

24. Melamed D, Nemazee D (1997) Self-antigen does not accelerate immature B cell apoptosis, but stimulates receptor editing as a consequence of developmental arrest. Proc Natl Acad Sci U S A 94: 9267-9272.

25. Melamed D, Benschop RJ, Cambier JC, Nemazee D (1998) Developmental regulation of $\mathrm{B}$ lymphocyte immune tolerance compartmentalizes clonal selection from receptor selection. Cell 92: 173-182.

26. Casellas R, Shih TA, Kleinewietfeld M, Rakonjac J, Nemazee D, et al. (2001) Contribution of receptor editing to the antibody repertoire. Science 291: 15411544.

27. Reth M, Gehrmann P, Petrac E, Wiese $P$ (1986) A novel $V_{H}$ to $V_{H} D_{H}$ joining mechanism in heavy-chain-negative (null) pre-B cells results in heavy-chain production. Nature 322: 840-842.

28. Kleinfield R, Hardy RR, Tarlinton D, Dangl J, Herzenberg LA, et al. (1986) Recombination between an expressed immunoglobulin heavy-chain gene and a germline variable gene segment in a Ly 1+ B-cell lymphoma. Nature 322: 843846.

29. Chen C, Nagy Z, Prak EL, Weigert M (1995) Immunoglobulin heavy chain gene replacement: a mechanism of receptor editing. Immunity 3: 747-755.

\section{Author Contributions}

Conceived and designed the experiments: LH MDL KS ZZ. Performed the experiments: LH MDL ZZ. Analyzed the data: LH MDL YY SL ZZ. Contributed reagents/materials/analysis tools: YY SL KS. Wrote the paper: LH MDL YY SL KS ZZ.

30. Cascalho M, Wong J, Wabl M (1997) $\mathrm{V}_{\mathrm{H}}$ gene replacement in hyperselected B cells of the quasimonoclonal mouse. J Immunol 159: 5795-5801.

31. Zhang Z, Zemlin M, Wang Y-H, Munfus D, Huye LE, et al. (2003) Contribution of $\mathrm{V}_{\mathrm{H}}$ gene replacement to the primary $\mathrm{B}$ cell repertoire. Immunity 19: 21-31.

32. Koralov SB, Novobrantseva TI, Konigsmann J, Ehlich A, Rajewsky K (2006) Antibody repertoires generated by $\mathrm{V}_{\mathrm{H}}$ replacement and direct $\mathrm{V}_{\mathrm{H}}$ to $\mathrm{J}_{\mathrm{H}}$ joining. Immunity 25: 43-53.

33. Lutz J, Muller W, Jack HM (2006) $\mathrm{V}_{\mathrm{H}}$ replacement rescues progenitor B cells with two nonproductive VDJ alleles. J Immunol 177: 7007-7014.

34. Chen C, Nagy Z, Radic MZ, Hardy RR, Huszar D, et al. (1995) The site and stage of anti-DNA B-cell deletion. Nature 373: 252-255.

35. Chen C, Prak EL, Weigert M (1997) Editing disease-associated autoantibodies. Immunity 6: 97-105.

36. Cascalho M, Ma A, Lee S, Masat L, Wabl M (1996) A quasi-monoclonal mouse. Science 272: 1649-1652.

37. Watson LC, Moffatt-Blue CS, McDonald RZ, Kompfner E, it-Azzouzene D, et al. (2006) Paucity of V-D-D-J Rearrangements and $\mathrm{V}_{\mathrm{H}}$ Replacement Events in Lupus Prone and Nonautoimmune TdT $-/-$ and $\mathrm{TdT}+/+$ Mice. J Immunol 177: $1120-1128$

38. Davila M, Liu F, Cowell LG, Lieberman AE, Heikamp E, et al. (2007) Multiple, conserved cryptic recombination signals in $\mathrm{V}_{\mathrm{H}}$ gene segments: detection of cleavage products only in pro B cells. J Exp Med 204: 3195-3208.

39. Kalinina O, Doyle-Cooper CM, Miksanek J, Meng W, Prak EL, et al. (2011) Alternative mechanisms of receptor editing in autoreactive B cells. Proc Natl Acad Sci U S A 108: 7125-7130.

40. Rogosch T, Kerzel S, Sikula L, Gentil K, Liebetruth M, et al. (2010) Plasma cells and nonplasma B cells express differing IgE repertoires in allergic sensitization. J Immunol 184: 4947-4954.

41. Zhang Z, Wang YH, Zemlin M, Findley HW, Bridges SL, et al. (2003) Molecular mechanism of serial $\mathrm{V}_{\mathrm{H}}$ gene replacement. Ann N Y Acad Sci 987: 270-273.

42. Hang LM, Izui S, Dixon FJ (1981) (NZW x BXSB)F1 hybrid. A model of acute lupus and coronary vascular disease with myocardial infarction. J Exp Med 154: 216-221.

43. Datta SK, Gavalchin J (1986) Origins of pathogenic anti-DNA idiotypes in the NZB X SWR model of lupus nephritis. Ann N Y Acad Sci 475: 47-58.

44. Eilat D, Webster DM, Rees AR (1988) V region sequences of anti-DNA and anti-RNA autoantibodies from NZB/NZW F1 mice. J Immunol 141: 17451753 .

45. Wloch MK, Alexander AL, Pippen AM, Pisetsky DS, Gilkeson GS (1997) Molecular properties of anti-DNA induced in preautoimmune NZB/W mice by immunization with bacterial DNA. J Immunol 158: 4500-4506.

46. Furukawa F (1997) Animal models of cutaneous lupus erythematosus and lupus erythematosus photosensitivity. Lupus 6: 193-202.

47. Mohan C, Morel L, Yang P, Watanabe H, Croker B, et al. (1999) Genetic dissection of lupus pathogenesis: a recipe for nephrophilic autoantibodies. J Clin Invest 103: 1685-1695.

48. Gaffney PM, Moser KL, Graham RR, Behrens TW (2002) Recent advances in the genetics of systemic lupus erythematosus. Rheum Dis Clin North Am 28: $111-126$.

49. Morel L (2010) Genetics of SLE: evidence from mouse models. Nat Rev Rheumatol 6: 348-357.

50. Sun Y, Liu Z, Li Z, Lian Z, Zhao Y (2012) Phylogenetic conservation of the $3^{\prime}$ cryptic recombination signal sequence $\left(3^{\prime} \mathrm{cRSS}\right)$ in the $\mathrm{V}_{\mathrm{H}}$ genes of jawed vertebrates. Front Immunol 3: 392.

51. Yazici ZA, Behrendt M, Goodfield M, Partridge LJ, Lindsey NJ (1998) Does the CDR3 of the heavy chain determine the specificity of autoantibodies in systemic lupus erythematosus? J Autoimmun 11: 477-483.

52. O'Keefe TL, Datta SK, Imanishi-Kari T (1992) Cationic residues in pathogenic anti-DNA autoantibodies arise by mutations of a germ-line gene that belongs to a large $\mathrm{V}_{\mathrm{H}}$ gene subfamily. Eur J Immunol 22: 619-624.

53. Suenaga R, Abdou NI (1993) Cationic and high affinity serum IgG anti-dsDNA antibodies in active lupus nephritis. Clin Exp Immunol 94: 418-422.

54. Radic MZ, Mackle J, Erikson J, Mol C, Anderson WF, et al. (1993) Residues that mediate DNA binding of autoimmune antibodies. J Immunol 150: 49664977.

55. Zhang Z, Burrows PD, Cooper MD (2004) The molecular basis and biological significance of $\mathrm{V}_{\mathrm{H}}$ replacement. Immunol Reviews 197: 231-242.

56. Sekiguchi DR, Eisenberg RA, Weigert M (2003) Secondary Heavy Chain Rearrangement: A Mechanism for Generating Anti-double-stranded DNA B Cells. J Exp Med 197: 27-39. 